Radovan Bacik,

PhD, Associate Professor, MBA, Head of the Department of Marketing and International Trade, Faculty of Management, University of Prešov in Prešov (Prešov, Slovak Republic);

Lukas Kakalejcik,

PhD Student, Department of Applied Mathematics and Business Informatics, Faculty of Economics, Technical University of Košice (Košice, Slovak Republic);

Beata Gavurova PhD, Associate Professor, MBA, Department of Banking and Investment, Faculty of Economics, Technical University of Košice (Košice, Slovak Republic)

\title{
INNOVATION OF SHOPPING EXPERIENCE BASED ON SMARTPHONE BEHAVIOR IN PURCHASING PROCESS
}

The main aim of the study is to analyze the use of smartphones by customers in the purchasing process and provide recommendations for innovation in shopping experience. In order to analyze interdependencies by defining the basic attributes of user clusters and their comparisons, data obtained from a consumer survey conducted by Google - Consumer Barometer was used. Factor analysis and k-means cluster analysis was executed in order to analyze the data and divide users into homogenous groups of users. By executing so, we have identified spatial correlations as a side product of our analysis. Based on the results it was possible to identify the most popular activities in the pre-purchasing stage - finding ideas, getting a store location, finding where to buy the product. The results pointed out to 2 groups of active smartphone users in terms of purchase, and 2 more conservative clusters mostly containing users from European countries. The results of our study will help e-commerce subjects to better understand the omnichannel behavior of users who are increasingly using mobile devices - smartphones - in the purchasing process.

Keywords: e-commerce, mobile devices, smartphone, smartphone adoption, mobile marketing.

DOI: $10.21272 / \mathrm{mmi} .2017 .4-9$

Introduction. Thanks to the development of the Internet and scientific and technological progress, the customer's purchasing cycle has become even more complex. First of all, it is necessary to mention the development of communication media that allowed customers access the information in the more favorable way. The variety of choices makes it hard for companies to select individual communication media according to the customers' taste (Scott D.M. [27]; Pal'ová D. and Vejačka M. [19]; Halligan B. and Shah D. [12]; Roberge M. [25]; Svatošová V. [30]; Hagyari P. and Fedorko R. [11]). On the other hand, the development of mobile devices means that users use more than one device during the purchasing process. The time when desktop computers were the only devices used for online shopping is gone. In 2016 , only $22 \%$ of Slovak Internet users used desktop computers, when compared to $70 \%$ in 2012 . The average Slovak Internet user owns 3 devices that he/ she regularly (sometimes even simultaneously) uses to access the Internet [3]. As a result, new innovations in marketing has arisen - mostly connected to the newborn features mobile devices provided to their users. Mobile telecommunications bear the immense importance in the economy, as it can enhance development and functioning of other sectors.

The growth in the number of user devices, as well as the process of linking online and offline environment led to the creation of a new type of user - omnichannel user. The model of omnichannel customer's behavior assumes that the customer will interact with the company using a number of channels and devices before the actual purchase (Dorman A.J. [7]). Deloitte [5] states that $9 \%$ of consumers in the United States own several mobile devices (smartphone, tablets and wearable devices). Juaneda-Ayensa et al. [14] refers to these users as 3.0 users. He states that these omnichannel users switch devices very often, which causes companies difficulties in controlling customers' purchasing processes. Edelman and Singer [8] as well as Alhlou et al. [1] implies that 
analyzing and customizing the purchasing process requires relevant experience during each step of the buying process. The issue of omnichannel users grabbed attention of companies and academics alike and a number of academics have already researched it, namely Piotrowicz W. and Cuthbertson R. [21], Peltola et al. [20], Lazaris et al. [17] and others. As interactive media created the ability to measure different results from online marketing campaigns [34], the problem is that omnichannel users cannot be tracked with ease and without restrictions regarding the results. However, new methods of omnichannel customer tracking has been developed (e. g. by Google [1]) which allowed marketers to implement 360 degree view to their marketing campaigns. Omnichannel users and their behavior is an issue that is beyond the scope of this study. However, basic theoretical bases are essential to investigating the behavior of smartphone users.

Poushter J. [23] in his study states that the amount of users owning a smartphone has increased sharply also in developing economies, but there are still significant differences when the smartphone ownership rate is compared for example with African countries. The author of the study also states a strong positive correlation between the ownership of smartphones with gross domestic product per capita. The study by Research New Zealand [24] states that between 2013 and 2015 the share of smartphone use in New Zealand increased to $46 \%$. In addition, the study states that daily use of other devices decreases. Deloitte [5] pointed to the fact that most respondents use a mobile phone while doing other activities such as shopping at the store, talking to family or friends, watching TV, or while eating in a restaurant. It gives companies the opportunity to reach their target customer almost anytime and everywhere but in times of massive commercial distraction, only innovative marketing ideas can persuade people to pay attention to or purchase the product.

Tossell et al. [32] using Smartphone Addiction Measurement Instrument studied on a sample of 34 students whether the use of smartphones under the predetermined conditions affects smartphone addiction. At the end of the experiment 21 out of 34 students agreed with the statement that they are addicted to their smartphones. Report Salesforce 2014 [26] also points out that only $85 \%$ of respondents see their mobile device as a central part of their everyday life, $90 \%$ of respondents aged between 18-24 years agreed. Holmes et al. [13] pointed out that in addition to the actual shopping smartphones are also used in the process of searching for information and alternatives. Mobile devices are used more often when it comes to buying products that require a higher level of engagement. Our own study carried out by Pollák et al. [22] and the complementing study Bucko et al. [2] showed that $96 \%$ of respondents combine desktop and mobile devices in various ratios. Moreover, the study showed that approximately $66 \%$ of respondents purchased a product using smartphones, while the most smartphones user use their device to search for product information (76\%), visit the website of a company (71\%), or search for product reviews (69\%). Google in 2015 announced that the number of searches on mobile devices surpassed the number of searches on desktop devices (Sterling G. [29]). This finding is directly related to the study carried out by DigitasLBi [6], which discusses the fact that customers have access to information about the product directly in the store which in turn influences their shopping behavior. The survey results showed that $77 \%$ of Internet users were influenced by a mobile device, $28 \%$ of users made their purchase via a mobile device. $55 \%$ of smartphone users think that the combination of the Internet and the smartphone has changed the way their shop at stores. Studies on the use of smartphones in the shopping process were published by the following academics and their collectives: Wang et al. [33], Einav et al. [9], Olivier X. and Treblanche N.S. [18], Thakur R. [31], Groß M. [10].

Based on the review of the above studies show that mobile device users cannot be overlooked when analyzing the user experience and its impact on sales of the company. Users use smartphones even during routine activities. In addition, it is clear that these devices are also used in the purchasing process, however, they are not yet dominant at the purchase stage. They rather serve as a full source of information in the information-seeking stage. Also, the positive experience on mobile device might result in positive brand image and thus, brand love [28]. These might be considered as arguments for Google to advocate mobile-first trend (the priority optimization of websites, ads, and content to be consumed on 
mobile screens) and devalue companies and publishers that don't stick to this trend [3].

The main objective of this study is to analyze different behavioral patterns of smartphone users during the pre-purchase stage of the purchase process based on the current knowledge and figure out the basis for innovations in customer journey optimization. By decomposing the main objective we have arrived to the following sub-objectives:

- analyze the current state of the issue of smartphones use with a focus on their use in the buying process;

- analyze the interdependencies between the variables included in the database and organizing factors in groups in order to reduce the number of variables;

- divide users by variables into homogeneous groups using the method of cluster analysis;

- define the basic attributes of the previously created clusters of users and compare these clusters.

Materials and methods. The behavior of smartphone users from selected countries was analyzed using data obtained from the consumer research carried out by Google - Consumer Barometer [4]. Data from this consumer survey were obtained from two sources. The first was a questionnaire that focuses on online population. The second one was a consumer study that aim was to calculate the total population of adults in order to adjust the results of the first part of the questionnaire. The questionnaire was conducted between January and April 2016. The data file contains data from 56 countries Europe (29), Asia (18), America (5), Africa (3) and Australia - a total of 78,920 respondents. The analysis posed the following question: "What kind of product research you made via your smartphone?" That question was posed to respondents in the questionnaire survey aimed at pre-purchase product research. The input variables are shown in Table 1.

Table 1 - Description of input variables (in \%) (developed by authors' study)

\begin{tabular}{|l|c|c|c|c|c|c|}
\hline \multicolumn{1}{|c|}{ Variable } & Min & $\begin{array}{c}\text { Lower } \\
\text { quartile }\end{array}$ & Median & Average & $\begin{array}{c}\text { Upper } \\
\text { quartile }\end{array}$ & Max \\
\hline A. Got ideas, inspiration online & 11,00 & 18,00 & 24,50 & 25,07 & 30,00 & 57,00 \\
\hline B. I found relevant brands online & 12,00 & 17,00 & 21,00 & 21,18 & 23,25 & 40,00 \\
\hline $\begin{array}{l}\text { C. Compared products, their } \\
\text { features and price online }\end{array}$ & 22,00 & 30,00 & 35,00 & 34,48 & 38,00 & 51,00 \\
\hline $\begin{array}{l}\text { D. Sought opinions/ review/ } \\
\text { advice online }\end{array}$ & 9,00 & 18,00 & 21,50 & 21,96 & 25,00 & 36,00 \\
\hline $\begin{array}{l}\text { E. Watched relevant videos } \\
\text { online }\end{array}$ & 4,00 & 8,75 & 10,50 & 10,29 & 12,00 & 16,00 \\
\hline $\begin{array}{l}\text { F. Searched for a relevant offer } \\
\text { online }\end{array}$ & 2,00 & 4,00 & 6,00 & 6,96 & 8,00 & 18,00 \\
\hline $\begin{array}{l}\text { G. Found where to buy/ product } \\
\text { availability online }\end{array}$ & 6,00 & 10,00 & 12,50 & 12,79 & 15,00 & 24,00 \\
\hline $\begin{array}{l}\text { H. Get store direction/ location } \\
\text { online }\end{array}$ & 3,00 & 9,00 & 12,50 & 12,54 & 15,00 & 26,00 \\
\hline $\begin{array}{l}\text { I. Made contact/ requested } \\
\text { contact (with brands/ retailers) }\end{array}$ & 3,00 & 4,00 & 6,00 & 5,95 & 7,00 & 12,00 \\
\hline $\begin{array}{l}\text { J. I was looking for online } \\
\text { financial options }\end{array}$ & 0,00 & 1,00 & 2,00 & 2,43 & 3,00 & 7,00 \\
\hline $\begin{array}{l}\text { K. Other information looked for } \\
\text { online }\end{array}$ & 3,00 & 7,00 & 10,00 & 10,52 & 14,00 & 20,00 \\
\hline
\end{tabular}

In order to analyze the data file we used the following statistical methods: 
- descriptive statistics (tables, bar charts, line charts, box plot, mean, median, quartiles);

- factor analysis;

- cluster analysis using k-means.

During the analysis we made use of The R Project and MS Excel.

Results. In the first step of the analysis we had to confirm that it is appropriate to use the factor analysis. Accordingly, the analysis is associated with the following steps:

- the analysis of the correlation matrix of variables;

- calculation of KMO and MSA statistics;

- implementation of the Bartlett test of sphericity.

The correlation matrix of variables is shown in Table 2.

Table 2 - Correlation matrix of variables (developed by authors' study)

\begin{tabular}{|c|c|c|c|c|c|c|c|c|c|c|c|}
\hline & A & B & C & D & E & F & G & H & I & J & K \\
\hline A & $\mathbf{1 , 0 0}$ & 0,12 & $-0,39$ & $-0,48$ & 0,24 & $-0,31$ & $-0,05$ & $-0,10$ & 0,20 & $-0,01$ & $-0,11$ \\
\hline B & 0,12 & 1,00 & 0,40 & 0,00 & 0,33 & 0,13 & 0,33 & 0,16 & 0,40 & 0,46 & $-0,39$ \\
\hline C & $-0,39$ & 0,40 & $\mathbf{1 , 0 0}$ & 0,30 & $-0,06$ & 0,40 & 0,20 & 0,32 & 0,07 & 0,10 & $-0,30$ \\
\hline D & $-0,48$ & 0,00 & 0,30 & 1,00 & 0,19 & 0,44 & 0,20 & 0,28 & 0,13 & 0,23 & 0,08 \\
\hline E & 0,24 & 0,33 & $-0,06$ & 0,19 & $\mathbf{1 , 0 0}$ & 0,31 & 0,41 & 0,37 & $\mathbf{0 , 5 1}$ & 0,40 & $-0,12$ \\
\hline F & $-0,31$ & 0,13 & 0,40 & 0,44 & 0,31 & $\mathbf{1 , 0 0}$ & 0,11 & 0,41 & 0,15 & $-0,09$ & $-0,20$ \\
\hline G & $-0,05$ & 0,33 & 0,20 & 0,20 & 0,41 & 0,11 & $\mathbf{1 , 0 0}$ & $\mathbf{0 , 7 1}$ & $\mathbf{0 , 6 4}$ & $\mathbf{0 , 5 1}$ & $-0,13$ \\
\hline H & $-0,10$ & 0,16 & 0,32 & 0,28 & 0,37 & 0,41 & $\mathbf{0 , 7 1}$ & $\mathbf{1 , 0 0}$ & $\mathbf{0 , 5 1}$ & 0,30 & $-0,20$ \\
\hline I & 0,20 & 0,40 & 0,07 & 0,13 & $\mathbf{0 , 5 1}$ & 0,15 & $\mathbf{0 , 6 4}$ & $\mathbf{0 , 5 1}$ & $\mathbf{1 , 0 0}$ & 0,41 & $-0,28$ \\
\hline J & $-0,01$ & 0,46 & 0,10 & 0,23 & 0,40 & $-0,09$ & $\mathbf{0 , 5 1}$ & 0,30 & 0,41 & $\mathbf{1 , 0 0}$ & 0,01 \\
\hline K & $-0,11$ & $-0,39$ & $-0,30$ & 0,08 & $-0,12$ & $-0,20$ & $-0,13$ & $-0,20$ & $-0,28$ & 0,01 & $\mathbf{1}, 00$ \\
\hline
\end{tabular}

The variables are labeled with letters in accordance with Table 3. The correlation matrix shows small, medium and large dependencies between the analyzed variables. Large dependencies (above $0,5)$ can be observed between the following variable pairs:

- made contact/requested contact (with brands/ retailers) and get store location (0,51);

- found where to buy/product availability online, requested contact (with brands/ retailers $(0,64)$;

- found where to buy/product availability online, get store direction/ location online $(0,71)$;

- found where to buy/product availability online, I was looking for online financial options $(0,51)$;

- get store direction/location online, made contact/requested contact (with brands/ retailers) $(0,51)$.

Based on these correlations, it is already possible to develop several marketing innovations. First of all, Al-based machine could analyze the behavioral pattern of the smartphone user and proactively offer information about the proximity of the store combined with the stock availability e. g. "This product is available in a store 2 kilometers away. Get directions." It could be also used to trigger a chatbot or live chat communication in order to assure user about his intended purchase.

Since the correlation matrix showed a dependency between variables, we proceeded with the implementation of further tests in order to determine the appropriateness of using the factor analysis. In 
order to carry out Kaiser-Mayer-Olkin test we standardized the data matrix's scale using z-scores. The total value of KMO test was 0,66, which according to Král' et al. [16] represents the average adequacy of the sample data. Since, however, this value is greater than 0,50 , it is suitable to carry out the factor analysis. All selected variables can be used within the analysis.

Table 3 - Principal components analysis (developed by authors' study)

\begin{tabular}{|l|c|c|c|c|c|c|c|c|c|c|c|}
\hline & K1 & K2 & K3 & K4 & K5 & K6 & K7 & K8 & K9 & K10 & K11 \\
\hline $\begin{array}{l}\text { Standard } \\
\text { deviation (own } \\
\text { number) }\end{array}$ & 1,90 & 1,43 & 1,18 & 1,04 & 0,93 & 0,73 & 0,63 & 0,62 & 0,53 & 0,50 & 0,40 \\
\hline $\begin{array}{l}\text { Cumulative } \\
\text { variability }\end{array}$ & 0,33 & 0,51 & 0,64 & 0,74 & 0,82 & 0,87 & 0,90 & 0,94 & 0,96 & 0,99 & 1,00 \\
\hline
\end{tabular}

In the next step we conducted a Batletts's sphericity test. In this test, we tested the following statistical hypotheses:

- HO: The correlation matrix of variables does not equal 1.

- HA: The correlation matrix of variables equals 1.

Since the $p$-value was $8,853188 \mathrm{e}^{-25}$, and thus was lower than the significance level $\alpha=0.05$, the null hypothesis was rejected. Since the correlation matrix of variables did not equal 1 , we accept the alternative hypothesis HA. In the next step we calculated the appropriate number of common factors. Firstly, we analyzed the principal components. The results are shown in Table 3. Since the value of own numbers is in the case of four components higher than 1, and the selection of these four components explains $74 \%$ of variation, the factor analysis will focus only on these 4 factors.

Since the saturation of several factors under one indicator was high, we had to implement different types of rotation - orthogonal (varimax, quartimax, equamax) and oblique (oblimin, promax). The best results were obtained when using equamax rotation. With three variables the saturation was relatively high, and therefore it is impossible to assign a particular variable to a factor. Therefore, three variables with high saturation were excluded from the analysis.

After removing these variables, it is necessary to repeat the whole process again. The value of KMO statistics was again at the level of 0.66 , which represents an average adequacy of sample data. In addition, Bartlett's sphericity test again rejected the null hypothesis that the correlation matrix equals one. The achieved $p$ value is in fact equal to $3.729983 \mathrm{e}^{-16}$, which is below the level of statistical significance of $a=0.05$. We thus proceeded to the analysis of the principal components in order to choose the appropriate number of factors for the factor analysis. Based on Table 4, we chose three factors for further analysis. Since the three components are greater than 1, and the proportion of cumulative variability is $71 \%$, we consider this selection to be correct.

Table 4 - Principal Components Analysis (developed by authors' study)

\begin{tabular}{|l|c|c|c|c|c|c|c|c|}
\hline & K1 & K2 & K3 & K4 & K5 & K6 & K7 & K8 \\
\hline Standard deviation (own number) & 1,73 & 1,29 & 1,01 & 0,89 & 0,77 & 0,64 & 0,58 & 0,47 \\
\hline Cumulative variability & 0,37 & 0,58 & 0,71 & 0,80 & 0,88 & 0,93 & 0,97 & 1,00 \\
\hline
\end{tabular}

After selecting factors (3), we proceeded to the factor analysis. To avoid an uncertain outcome, we performed a rotation of factors. Since it was our intention to work with uncorrelated factors, we made use only of orthogonal rotation. Using the quartimax and equamax methods we achieved excellent results - 

покупок

factor saturation of individual factors was really high. Although we did not arrive at the same high saturation of factors using the varimax method, we were able to eliminate the influence of a single indicator on several factors. Therefore, the varimax method was preferred. Factor saturation is shown in Table 5.

Table 5 - Saturation matrix (varimax rotation) (developed by authors' study)

\begin{tabular}{|c|c|c|c|c|c|}
\hline Variables (indicators) & F1 & F2 & F3 & $h^{2}$ & $u^{2}$ \\
\hline A. Got ideas, inspiration online & 0,18 & $-0,90$ & 0,03 & 0,84 & 0,16 \\
\hline B. I found relevant brands online & 0,31 & $-0,09$ & 0,72 & 0,63 & 0,37 \\
\hline D. Sought opinions/ review/ advice online & 0,27 & 0,77 & $-0,10$ & 0,67 & 0,33 \\
\hline E. Watched relevant videos online & 0,74 & $-0,17$ & 0,05 & 0,59 & 0,41 \\
\hline G. Found where to buy/ product availability online & 0,83 & 0,19 & 0,14 & 0,74 & 0,26 \\
\hline H. Get store direction/ location online & 0,76 & 0,30 & 0,11 & 0,68 & 0,32 \\
\hline I. Request contact details/ contacted company & 0,80 & $-0,1$ & 0,28 & 0,72 & 0,28 \\
\hline K. Sought other information & $-0,05$ & 0,03 & $-0,88$ & 0,79 & 0,21 \\
\hline
\end{tabular}

Based on the factor analysis we arrived at the following three factors:

- Factor 1: watching relevant videos, verifying product availability, getting store directions, contacting the brand/store;

- Factor 2: looking for ideas/inspiration, reviews and opinions;

- Factor 3: searching for brands, looking for information.

Factor 1 can be explained as a factor representing a greater commitment to purchasing a product. It includes the activities that get user in a direct contact with the brand. However, the presence of the variable "watching relevant videos" in this group cannot be interpreted. On the other hand, as an innovation in marketing communication, while user is watching the video, the Al-based machine can trigger the information regarding the availability of the product surrounded by the option to get directions to the close store or contact the store. Factor 2 could be defined as the initial phase of in the search for the products. As the Factor 2 involves variables such as search for ideas, reviews and opinions followed by the search for suitable alternatives, this factor acts as a huge factor in the awareness phase. If provided together, idea with the factor of social proof might work as a persuasive technique in order to either create more desire or to move customer faster throughout the marketing/sales funnel. Factor 3 cannot be interpreted in a straightforward way as we did not establish the importance behind finding other information. Overall, it can be concluded that factors cannot be clearly interpreted. Since the reduction of the number of variables is important for the cluster analysis, failure to interpret the factors is not significant for the results of this study. Factor saturations have helped us to create 3 new latent variables containing factor scores that will be used as input data for cluster analysis. The last step before starting the cluster analysis itself is to verify the assumption that there is no dependence between newly created variables. For this purpose, we have compiled a correlation matrix as shown in Table 6.

As can be seen, the correlations between the factors are close to zero, thus confirming that the result of orthogonal rotation is uncorrelated factors. Once all the assumptions have been made, we can carry out the cluster analysis. 
Table 6 - Correlation matrix of factors (developed by authors' study)

\begin{tabular}{|l|c|c|c|}
\hline & Factor 1 & Factor 2 & Factor 3 \\
\hline Factor 1 & 1,00 & $2.830630 \mathrm{e}^{-16}$ & $-4.214035 \mathrm{e}^{-16}$ \\
\hline Factor 2 & $2.830630 \mathrm{e}^{-16}$ & 1,00 & $1.165143 \mathrm{e}^{-15}$ \\
\hline Factor 3 & $-4.214035 \mathrm{e}^{-16}$ & $1.165143 \mathrm{e}^{-15}$ & 1,00 \\
\hline
\end{tabular}

The first step of the cluster analysis was to determine the appropriate number of clusters, using the Figure 1. Y-axis in the Figure 1 represents the ratio of the sum of squares between the clusters and the total sum of squares. When choosing the number of clusters, this ratio should be, however, as high as possible. When choosing the right number of clusters it is necessary to take into account the curvature of the displayed line. When choosing an appropriate number of clusters it is advisable to choose such a point at which the line breaks significantly. In Figure 1, this condition can be monitored especially when 4 or 7 clusters are observed. Due to the size of the data file and possible problems with cluster defining this study will employ $\mathrm{k}$-means method using four clusters.

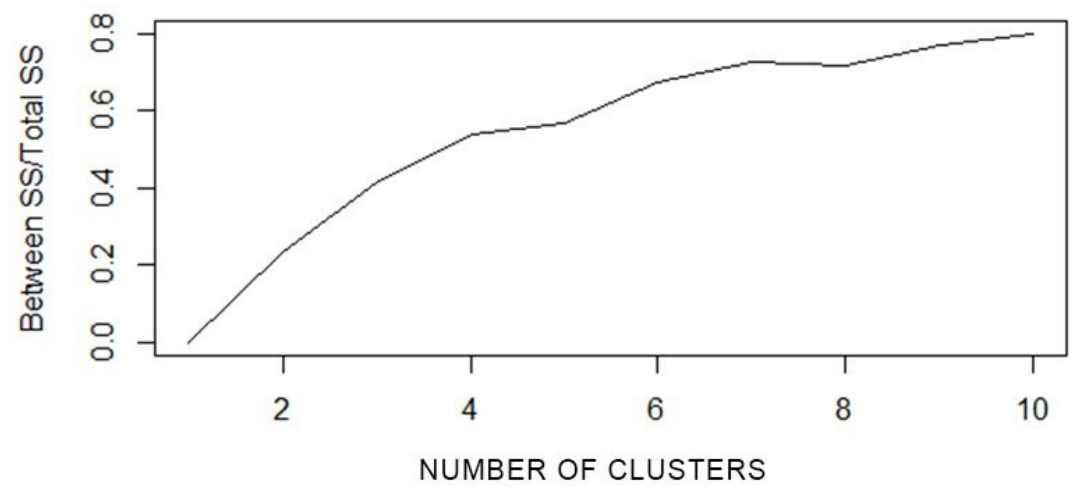

Figure 1 - Selecting suitable number of clusters (k-means)

(developed by authors' study)

After selecting the appropriate number of clusters we were able to proceed with the actual cluster analysis.

Using the k-means method we defined 4 clusters consisting of the following countries:

- Cluster 1: Austria, Belgium, Denmark, France, Germany, Hungary, Lithuania, Latvia, Netherlands, Norway, Poland, Portugal, Sweden, Switzerland, Thailand;

- Cluster 2: Bulgaria, Croatia, Estonia, Greece, Russia, Serbia, Slovenia, Ukraine, China, Malaysia, Singapore, Vietnam, Argentina;

- Cluster 3: Australia, India, New Zealand, Philippines, Canada, United States of America, Saudi Arabia, Turkey, United Arab Emirates, Nigeria, South Africa;

- Cluster 4: Czech Republic, Finland, Ireland, Italy, Romania, Slovakia, Spain, United Kingdom, Hong Kong, Indonesia, Japan, South Korea, Taiwan, Brazil, Mexico, Israel, Kenya.

The clusplot in Figure 2 shows the division of countries into clusters with respect to components obtained by factor analysis. Figure 3 shows the geographic distribution of clusters. In many clusters, spatial correlations can be observed. For example, Custer 1 represents almost a single territory, with 
only Portugal and Thailand outlying. Even in the case of Cluster 2, it is possible to see that Russia and China form the largest area, but their neighbors are also in the cluster. The least spatial correlations can be observed in the case of Cluster 3 and Cluster 4. Cluster 3 occupies relatively large part of the territory including North America (USA and Canada), Australia, Asian and African countries.

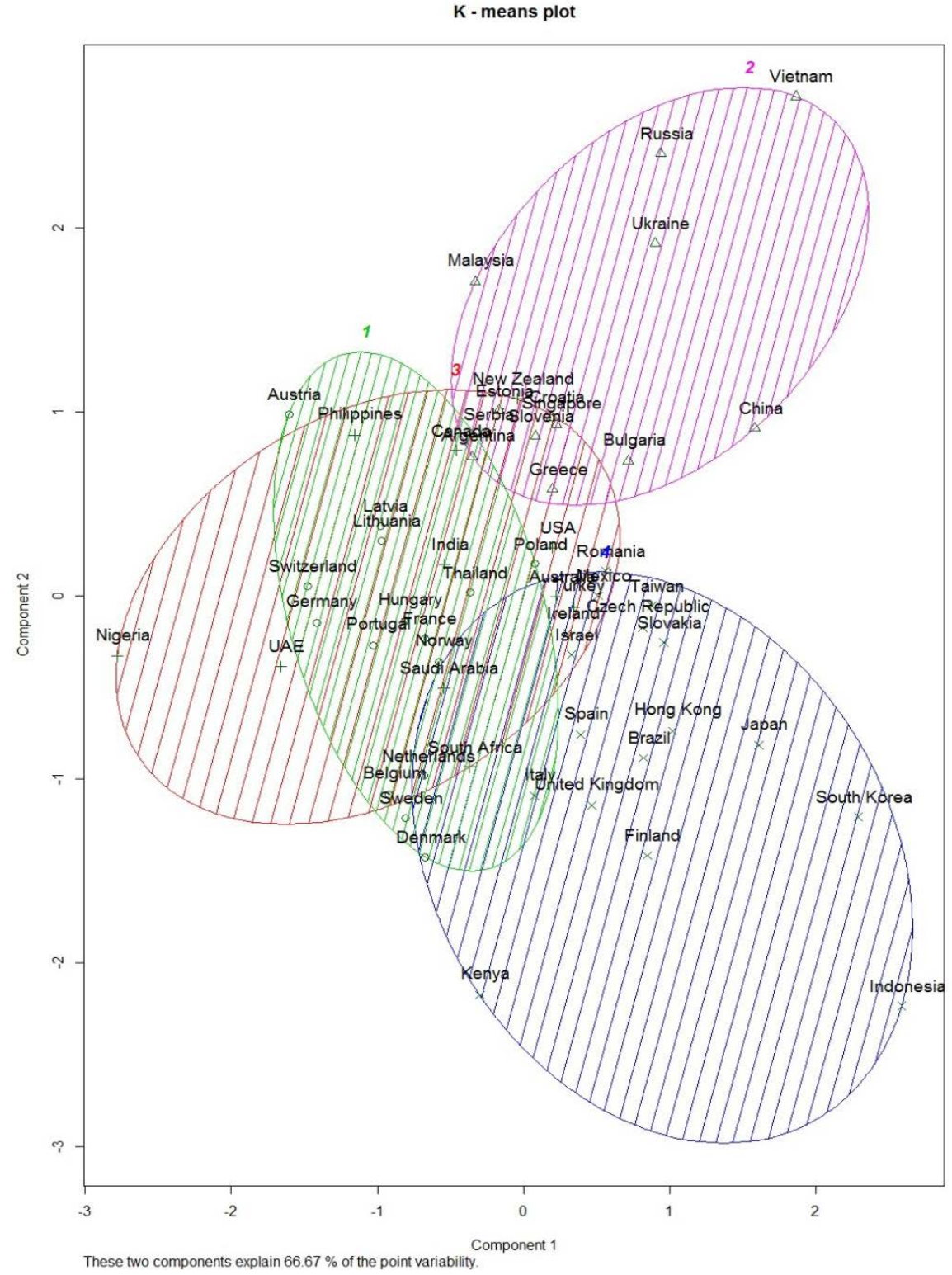

Figure 2 - Clusplot (k-means, 4 clusters) (developed by authors' study)

If Turkey was not considered a European country, this cluster would be the only one that does not 
include at least one European country. Cluster 4 includes European countries that did not make it into Cluster 1 and 2, Mexico, Brazil, Kenya and the rest of the eastern and southeast Asian countries.

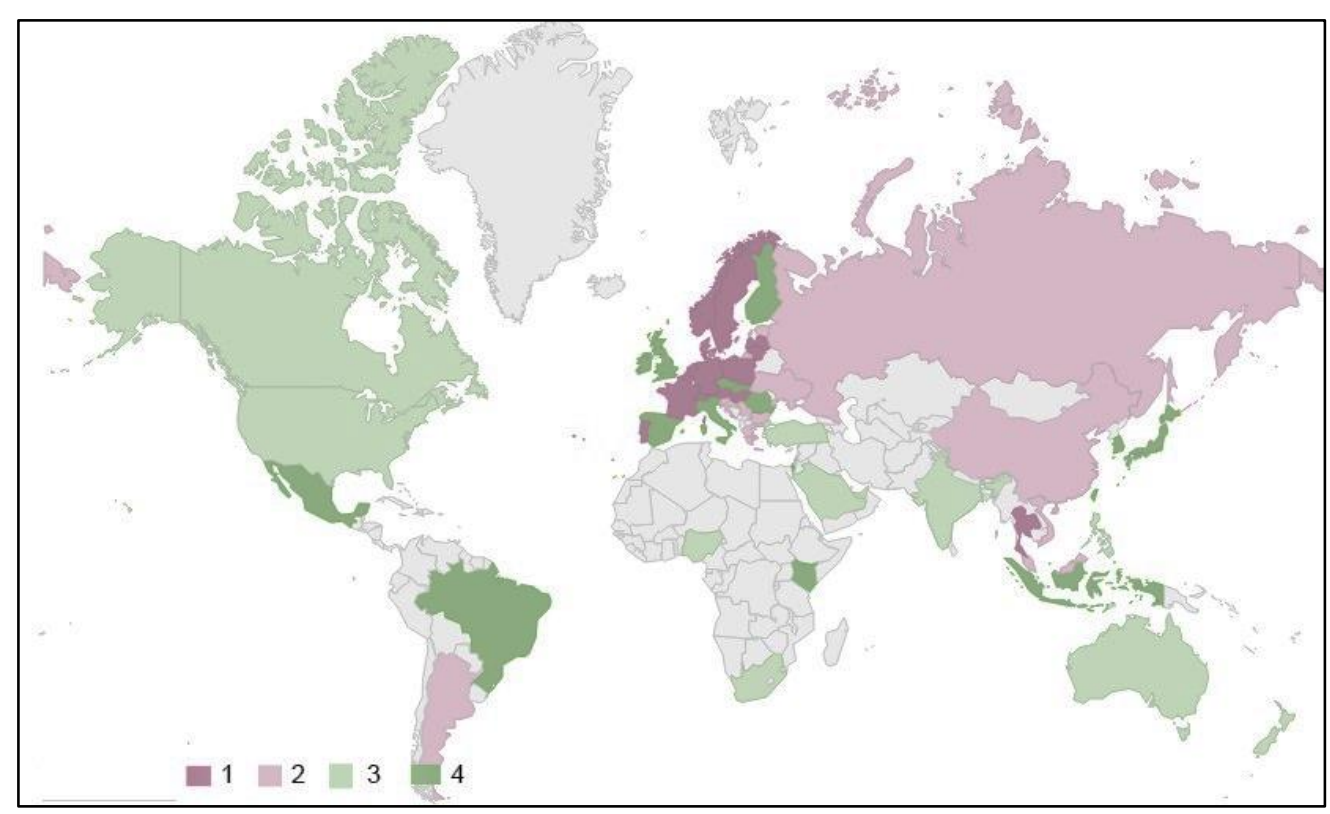

Figure 3 - Geographic distribution of clusters (developed by authors' study)

More than geographic representation of countries in clusters, the goal of this study is to define the differences between smartphone users in specific clusters. For this purpose, the mean values were calculated for the individual variables, and their comparison can be seen in Figure 4. Based on Figure 4, it's possible to see that users belonging to Cluster 1 use their smartphones mostly to find ideas or inspiration.

For this variable, Cluster 1 achieves the second highest level (25\%). The second most widely spread activity on a smartphone in case of Cluster 1 is to get store direction or instructions for finding it. 15\% of users in Cluster 1 also use the smartphone to find places where the product can be purchased. Interestingly enough, users in Cluster 1, compared to other clusters, use their smartphone to find the other information. In total, it is possible to say that users in Cluster 1 are the least active user groups. As this cluster is the made of backbone European countries, we can label these European countries as conservative with regard to their use of smartphones in the pre-purchase phase of the purchasing cycle. Conversely, users from countries belonging to Cluster 2 are among the most active smartphone users in the pre-purchase phase of the buying process. The users use their smartphones to get store direction they hold the overall primacy between the clusters. The second most popular activity is finding a place where goods can be purchased. The third most popular activity is finding ideas or inspiration. Users in Cluster 2 use smartphones on average the most when looking for relevant brands, viewing relevant videos and contacting a store or requesting a contact from a store. Users in Cluster 2 are active on their smartphones during their pre-purchase phase. As an incentive for further analysis we propose to investigate the reasons why residents of these countries use their smartphones to such an extent. Cluster 3 dominates in case of the variable in "inspiration" with an average of $37 \%$ of users. The second 

покупок

most popular smartphone activity in the pre-purchase process was "where to buy a product", the third was "store location or instructions to find it". These users also use their smartphones to find opinions and ratings of products. Since Cluster 3 features United States and Canada, where the Yelp platform is very popular, we assume that this factor has influenced the results. For other activities, it can be argued that users in Cluster 3 use their smartphones to a similar extent as users in Cluster 2, with no significant difference between them.

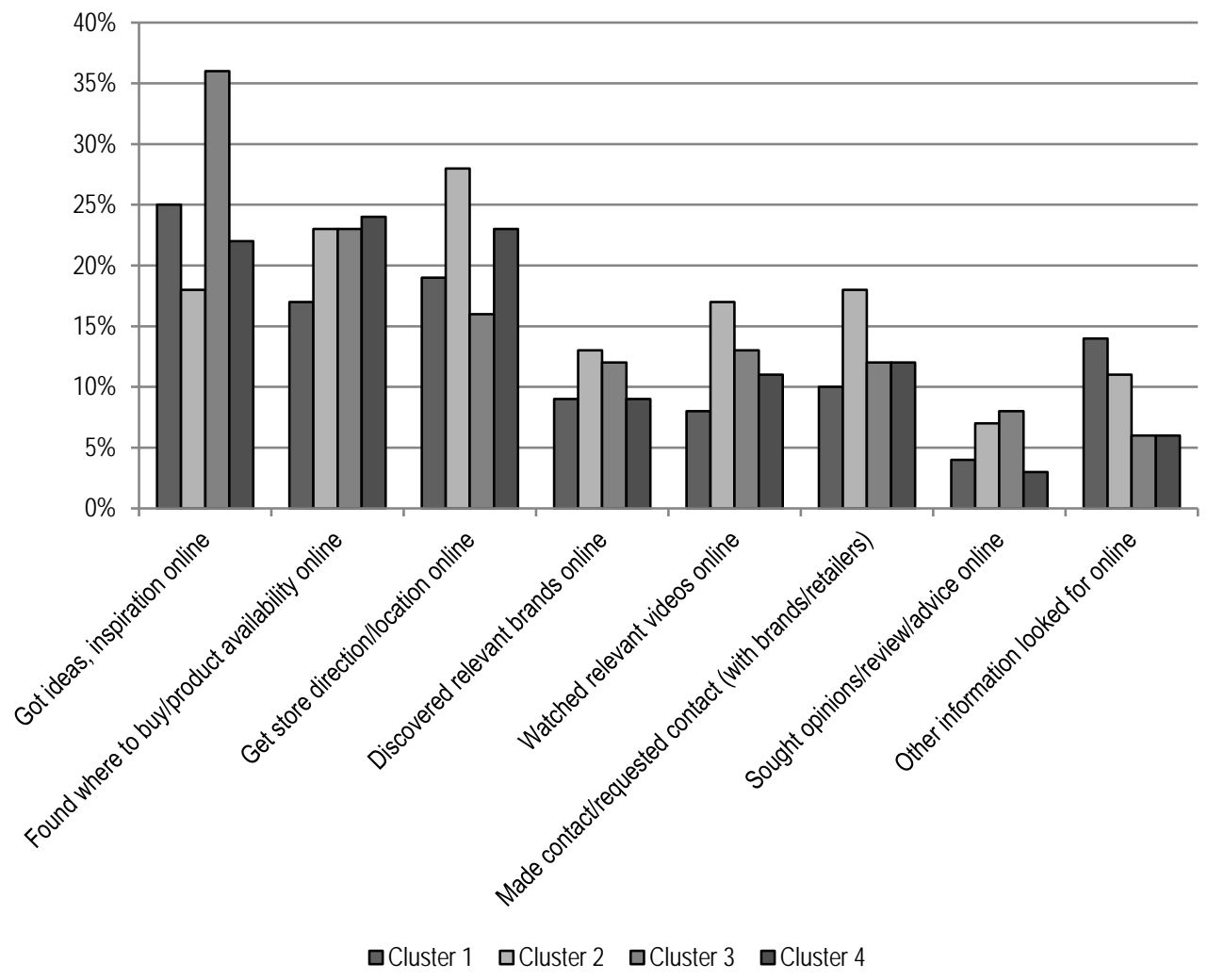

Figure 4 - Comparison of the mean values of the variables in the analyzed clusters (k-means) (developed by authors' study)

Similarly to Cluster 1 , Cluster 4 contains more conservative users, who are slightly more active when using smartphones than users in Cluster 1. Among the three most common activities, as in the case of the previous clusters, is the variable "get store location", "where to buy a product", and "search for ideas and inspiration online".

In general, the following conclusions can be drawn:

- although it is possible to divide countries with more active and less active smartphone users into cluster, the most popular activities in the pre-purchase process are looking for ideas, where to buy the product and the location of the store. Other activities are not carried out to a large extent. It is possible to spot ROPO effect (research online, purchase offline) in this case, as users in pre-purchase stage are looking for offline places to purchase the product. In such a scenario, it is possible to conclude that by 
providing shoppers with the option to find a near-by store and get directions to it, it is possible to drive offline store traffic and gain revenue from, in other cases, mobile shoppers.

- users in Cluster 2 are using smartphones to the fullest extent, so it makes the most sense to optimize the pre-purchase activities for mobile devices. Moreover, this Cluster has a great potential for the implementation of marketing innovations designed to be used on mobile devices.

- clusters containing European countries (with the exception of Cluster 2) show low smartphone usage in the pre-sales process, indicating user conservatism in these countries. However, it is not clear if innovations in the marketing communications targeted to these users might be useless or supporting in terms of mobile purchasing.

Discussion. Even during the analysis of input variables, we were able to find the match with the work of Dorman A.J. [7] who assumes that users are in the interaction with the company by using more channels and more importantly for our study, more than one device. As the values observed in all variables did not equal to $100 \%$ (moreover, in the majority of countries, it was less than $50 \%$ ), this study confirms the existence of omnichannel users based on the assumption that the rest of the users execute the activities either via desktop computer or other mobile device. As Pushter J. [23] stated, smartphone ownership grows significantly in developing countries. The results of our cluster analysis shown that users especially from developing countries shown higher adoption of smartphones in the purchasing process and therefore are better candidates for innovations in marketing communication. On the other hand, the results of our study don't match with conclusions by Holmes et al. [13] who stated that smartphones are mostly used in the pre-purchase stage. We found out that with the exception of Cluster 2 and 3, smartphones are commonly used only for inspiration finding, checking out the availability of the product, as well as finding out the store in the area. Smartphones are not broadly used for other observed activities connected with this stage of the purchase process.

Moreover, by comparing our results with our previous studies [2; 22] we found out differences in smartphone adoption in the pre-purchase stage, especially when it came to finding information regarding the product, product research and looking for a store in the closest area. As our previous studies were conducted on the sample consisting users from Generation $Y$, we assume that these users are more engaged in mobile technology in the purchasing process.

Based on our results, as well as the results resulting from previous studies, we can conclude that smartphones are indeed important ICT tools useful for users within purchasing process. It is possible to predict that as current Generation $Y$ will get older, the adoption of smartphones in the purchasing process will increase and mobile-first trend will reach the gigantic dimension.

Conclusion. Our present is characterized by the continuing progress in the field of digital technologies. This is the most apparent in the case of the online environment where innovations are constantly changing the way we communicate. The Internet as a constantly changing and evolving organism penetrates almost into all the dimensions of business entities providing their goods and services on the market. The main aim of the study was to analyze the use of smartphones by customers in the purchasing process based on established theoretical backgrounds and provide suggestions to innovate purchasing process for smartphone users.

The massive expansion of mobile services and the high popularity of smartphones among users is an opportunity for organizations to expand or optimize their sales channels. In our opinion, the trend of popularity in the use of smartphones will continue. Based on the studies we have described, it is clear that smartphones are used in the buying process, although they are not dominant at the purchasing stage. These devices can be characterized as a full-featured source of information in the search for product information.

The above-described findings in the analysis of the use of smartphones by customers in the purchasing process can be considered highly relevant from the point of view of theory and practice. Our 
findings, based on the answers of 78920 respondents from 56 countries, have the ambition to help market participants better understand the user preferences and motives that influence the online shopping process.

We were able to determine four groups of smartphone users who could be subdivided into two main groups - users engaged to smartphones in the purchasing process and to those who are not. It was found that users from developing economies are more engaged in the smartphones. On the contrary, users from European countries appears to be more conservative. Moreover, it was found out that mobile shoppers follow ROPO effect, as they are looking for places where to purchase product offline after searching for it online in the pre-purchase stage.

As the development of mobile devices made users use not only one device during the purchasing process, it will be interesting to see how the trend will be reflected on the business entities part marketing activities in the form of modern and innovative forms of online shopping. The comfort and immediacy in the use of mobile devices in conjunction with ongoing innovations will result in further growth in the popularity of using mobile devices, especially in the online shopping.

1. Alhlou, F., Asif, S., \& Fettman, E. (2016). Google Analytics Breakthrough: From Zero to Business Impact. John Wiley \& Sons.

2. Bucko, J., Kakalejčík, L., \& Nastišin, L'. (2015, September). Use of smartphones during purchasing process. In Central European Conference in Finance and Economics (CEFE2015), Technical University of Košice, 91-97.

3. Consumer Barometer (2017a). Trended data. www.consumerbarometer.com. Retrieved from https://www.consumerbarometer.com/en/trending/?countryCode=SK\&category=TRN-NOFILTER-ALL.

$\begin{array}{llll}\text { 4. Consumer Barometer (2017b). Methodology. www.consumerbarometer.com. Retrieved } & \end{array}$ from:https://www.consumerbarometer.com/en/about/.

5. DELOITTE (2015). 2015 Global Mobile Consumer Survey: US Edition The rise of the always-connected consumer www2.deloitte.com. Retrieved from https://www2.deloitte.com/content/dam/Deloitte/us/Documents/technology-mediatelecommunications/us-tmt-global-mobile-executive-summary-2015.pdf.

$\begin{array}{lllll}6 . & \text { DIGITASLBI (2015). } & \text { Connected Commerce. www.digitaslbi.com. Retrieved from }\end{array}$ http://www.digitaslbi.com/Global/ConnectedCommerce2015-Deck-FINAL.pdf.

7. Dorman, A.J. (2013). Omni-Channel Retail and the New Age Consumer: An Empirical Analysis of Direct-to-Consumer Channel Interaction in the Retail Industry (senior thesis). Retrieved from Claremont: Claremont McKenna College.

8. Edelman, D.C., \& Singer, M. (2016). Competing on Customer Journeys. Measuring Marketing Insights: Turning Data into Action. www.google.com. Retrieved from https://www.google.com/analytics/resources/white-paper-hbr-measuring-marketinginsights-collection.html.

9. Einav, L., Levin, J., Popov, I., \& Sundaresan, N. (2014). Growth, adoption, and use of mobile E-commerce. The American economic review, 104(5), 489-494.

10. Groß, M. (2015). Mobile shopping: a classification framework and literature review. International Journal of Retail \& Distribution Management, 43(3), 221-241.

11. Hagyari, P., Bacik, R., \& Fedorko, R. (2016). Analysis of the key factors of reputation management in conditions of city marketing. Polish Journal of Management Studies, 13(1), 69-80.

12. Halligan, B., \& Shah, D. (2014). Inbound Marketing: Get found using Google, Social Media and Blogs. New Jersey: John Wiley \& Sons.

13. Holmes, A., Byrne, A., \& Rowley, J. (2013). Mobile shopping behaviour: insights into attitudes, shopping process involvement and location. International Journal of Retail \& Distribution Management, 42(1), 25-39.

14. Juaneda-Ayensa, E., Mosquera, A., \& Murillo, Y. S. (2016). Omnichannel customer behavior: key drivers of technology acceptance and use and their effects on purchase intention. Frontiers in psychology, 7, 1-11.

15. Korchagin, P., Korneeva, E., \& Nikitina, N. (2015). Factors that Influence the Effectiveness of Russian Telecommunication Companies. Economics \& Sociology, 8(3), 119-130.

16. Král', P., Kanderová, M., Kaščáková, A., Nedelová, G., \& Valenčáková, V. (2009). Viacrozmerné štatistické metódy so zameraním na riešenie problémov ekonomickej praxe. Banská Bystrica: Ekonomická fakulta UMB. [In Slovak].

17. Lazaris, C., Vrechopoulos, A. P., Doukidis, G. I., \& Fraidaki, A. (2015). Mobile Apps for Omnichannel Retailing: Revealing the Emerging Showroom Phenomenon. In MCIS.

18. Olivier, X., \& Treblanche, N. S. (2016). An investigation into the antecedents and outcomes of the m-shopping experience. The Business and Management Review, 7(5), 263-267.

19. Palová, D., \& Vejačka, M. (2015). FASTER Platform - an Online Tool for EU Accountants Education. MIPRO 2015, Rijeka: Croatian Society for Information and Communication Technology, Electronics and Microelectronics, 838-843.

20. Peltola, S., Vainio, H., \& Nieminen, M. (2015, August). Key factors in developing omnichannel customer experience with finnish retailers. In International Conference on $\mathrm{HCl}$ in Business (pp. 335-346). Springer, Cham. 
21. Piotrowicz, W., \& Cuthbertson, R. (2014). Introduction to the special issue information technology in retail: Toward omnichannel retailing. International Journal of Electronic Commerce, 18(4), 5-16.

22. Pollák, F., Nastišin, L., \& Kakalejčík, L. (2015). Analysis of the Use of Smartphones during Purchasing Process for a Selected Group of Customers within Slovak Market Conditions. Management: Science and Education, 4(1), 77-79.

23. Poushter, J. (2016). Smartphone Ownership and Internet Usage Continues to Climb in Emerging Economies. www.pewglobal.org. Retrieved from http://www.pewglobal.org/files/2016/02/pew_research_center_global_technology_report_final_ february_22_2016.pdf.

24. Research New Zealand (2015). A Report on a Survey of New Zealanders' Use of Smartphones and other Mobile Communication Devices 2015. www.researchnz.com. Retrieved from: http://www.researchnz.com /pdf/special\%20reports/research\%20new\%20zealand\%20special\%20report\%20-\%20use\%20of\%20 smartphones.pdf.

25. Roberge, M. (2015). The Sales Acceleration Formula: Using Data, Technology, and Inbound Selling to go from $\$ 0$ to $\$ 100$ Million. Hoboken: John Wiley \& Sons.

26. SALESFORCE (2014). 2014 Mobile Behavior Report: Combining mobile device tracking and consumer survey data to build a powerful mobile strategy. www.marketingcloud.com. Retrieved from https://www.marketingcloud.com/sites/exacttarget/files/deliverables/etmc-2014mobilebehaviorreport.pdf.

27. Scott, D.M. (2013). The New Rules of Marketing \& PR: How to Use Social Media, Online Video, Mobile Applications, Blogs, News Releases \& Viral Marketing to Reach Buyers Directly. New Jersey: John Wiley \& Sons.

28. Shirkhodaie, M., \& Rastgoo-deylami, M. (2016). Positive Word of Mouth Marketing: Explaining the Roles of Value Congruity and Brand Love. Journal of Competitiveness, 8(1), 19-37.

29. Sterling, G. (2015). It's Official: Google Says More Searches Now On Mobile than On Desktop. searchengineland.com. Retrieved from: http://searchengineland.com/its-official-google-says-more-searches-now-on-mobile-than-on-desktop-220369.

30. Svatošová, V. (2013). Motivation of Online Buyer Behavior. Journal of Competitiveness, 5(3), 14-30.

31. Thakur, R. (2016). Understanding customer engagement and loyalty: a case of mobile devices for shopping. Journal of Retailing and Consumer Services, 32, 151-163.

32. Tossell, C., Kortum, P., Shepard, C., Rahmati, A., \& Zhong, L. (2015). Exploring Smartphone Addiction: Insights from Long-Term Telemetric Behavioral Measures. International Journal of Interactive Mobile Technologies, 9(2), 37-43.

33. Wang, R. J. H., Malthouse, E. C., \& Krishnamurthi, L. (2015). On the go: How mobile shopping affects customer purchase behavior. Journal of Retailing, 91(2), 217-234.

34. Watrobski, J., Jankowski, J., \& Ziemba, P. (2016). Multistage Performance Modelling in Digital Marketing Management. Economics \& Sociology, 9(2), 101-119.

P. Бачик, PhD, доцент, MBA, завідувач кафедри маркетингу і міжнародної економіки, Факультет менежменту, Пряшівський університет в Пряшеві (м. Пряшів, Словацька Республіка);

Л. Какалейчик, аспірант кафедри прикладної математики та інформатики підприємств, Економічний факультет, Технічний університет в Кошицях (м. Кошице, Словацька Республіка);

Б. Гавурова, PhD, доцент, MBA, кафедра інвестицій та банківської справи, заступник декана з науково-дослідної роботи, Економічний факультет Технічний університет в Кошицях (м. Кошице, Словацька Республіка)

Дослідження особливостей використання смартфонів у процесі здійснення покупок

у статmі досліджено особливості використання смартфонів споживачами в процесі здійснення покупок. Під час дослідження проаналізовано дані сервісу «Consumer Barometer» за допомогою факторного аналізу i кластера k-mеans. 3 точки зору здійснення покупок до уваги бралися дві групи активних і дві групи консервативних користувачів смартфонів.

Ключові слова: електронний ринок, мобільні пристрої, смартфон, прийняття смартфонів, мобільний маркетинг.

P. Бачик, PhD, доцент, MBA, заведующий кафедры маркетинга и международной экономики, Факультет менежмента, Прешовский университет в Прешове (г. Прешов, Словацкая Республика);

Л. Какалейчик, аспирант кафедры прикладной математики и информатики предприятий, Экономический факультет, Технический университет в Кошице (г. Кошице, Словацкая Республика);

Б. Гавурова, PhD, доцент, MBA, кафедра инвестиций и банковского дела, заместитель декана по научноисследовательской работе, Экономический факультет, Технический университет в Кошице (г. Кошице, Словацкая Республика)

Исследование особенностей использования смартфонов в процессе осуществления покупок

В статье исследованы особенности использования смартфонов в процессе осуществления покупок. Во время исследования проанализированы данные сервиса "Consumer Barometer» с помощью факторного анализа и кластера kmeans. C точки зрения осуществления покупок брались в расчет две группы активных и две групп консервативных пользователей смартфонов.

Ключевые слова: электронный рынок, мобильные устройства, смартфон, принятие смартфонов, мобильный маркетинг.

Отримано 11.05.2017 p. 